\title{
УДК: 619:576.8.095.1
}

МІНЦЮК Є.П.*, e-mail: jeckmints@ gmail.com, НИЧИК С.А., д-р вет. наук, проф., e-mail: ivm_naan@ukr.net, ГОРБАТЮК О.І., канд. вет. наук, доц., e-mail: goroliva@ukr.net, РИЖЕНКО Г.Ф., канд. біол. наук, доц., e-mail: anaerob12@ukr.net, АНДРІЯЩУК В.О., канд. вет. наук, e-mail: and_valentina@hotmail.com, ЖОВНІР О.М., канд. вет. наук, e-mail: Zhovnir73@ukr.net, УХОВСБКА Т.М., канд. вет. наук, e-mail: tanyavet@ukr.net, ТЮТЮН C.M., e-mail: anaerob12@ukr.net, Інститут ветеринарної медицини НААН

РЕЗНІЧЕНКО Л.С., канд. біол. наук, ст. наук. сп., e-mail: reznichenko_ls@mail.nu, ДИБКОВА С.М., канд. біол. наук, ст. наук. сп., e-mail: sdybkova@gmail.com Інститут біоколоїдної хімї ім. Ф. Д. Овчаренка НАН України

\section{СПОСІБ ПОЛПШЕННЯ РОСТОВИХ ЯКОСТЕЙ ЖИВИЛЬНОГО СЕРЕДОВИЩА ДЛЯ АНАЕРОБІВ ЗА ЗАСТОСУВАННЯ НАНОЧАСТИНОК МІДІ}

У статті представлений аналіз результатів експериментальних досліджень, які були пов'язані з поліпшенням ростових властивостей рідкого живильного середовища для анаеробних бактерій $C$. perfringens типи $A, B, C$, Д після додавання до його складу наночастинок міді (CиNP) у концентрачіях 0,080; 0,040 і 0,008 мг/мл з метою накопичення великих об'ємів бактеріальної маси збудника за короткі терміни культивування. Наночастинки міді з розрахунку 0,008 мг/мл у кінцевій концентрачї забезпечували зростання об'ємів бактеріальної маси збудника вірогідно у 1,9 разів ( $>>0,001)$, порівняно $з$ аналогічними показниками за ї̈ росту на живильному середовищі без вмісту СиNP, упродовж 12 год культивування у термостаті за $37^{\circ} \mathrm{C}$, щзо має важливе значення для біотехнології виготовлення вакцин.

Ключові слова: рідке жсивильне середовище для анаеробів, наночастинки міді, CuNP, концентрації нанопрепарату, C. perfringens, інтенсивність росту, бактеріальна маса.

Вступ. Вивчення особливостей впливу наночастинок металів на процеси обміну клітин мікроорганізмів нині є актуальним завданням медицини, біології і біотехнології.

Аналіз наукової літератури, незважаючи на широкий спектр досліджень в області нанотехнологій, показав, що найчастіше увага дослідників зосереджена на вивченні біологічних ефектів від впливу наночастинок металів на мікроорганізми - бактерицидних та бактеріостатичних [1-7].

Наразі недостатньо наукової інформації щодо можливостей використання наночастинок металів в якості стимуляторів росту i розмноження клітин збудників бактеріальних інфекцій $[1,2,8]$. Процеси життєдіяльності бактерій пов'язані із іхнім метаболізмом, спрямованим на синтез АТФ, завдячуючи чому, вони спроможні синтезувати власні структурні елементи та ферменти, які

\footnotetext{
* Пошукач
} 
здатні такі структури руйнувати. Одним із важливих процесів за обміну речовин у анаеробних i аеробних збудників є метаболізм органічних речовин, зокрема мікроелементів. Вони входять до складу ферментів бактерій, тому у обміні речовин виконують особливу функцію - інгібуючу обмін або його стимулюючи [8-10]. Тому, за виготовлення живильних середовищ для культивування патогенних збудників необхідною умовою є наявність у їхньому складі поживних речовин, які б забезпечували ріст і розмноження бактерій. Під час культивування у рідкому живильному середовищі спостерігається поступова зміна фаз розвитку бактеріальної культури латентної (початкової, Lag-фази) тривалістю упродовж 1-2 год, експоненціальної (логарифмічного росту) тривалістю 5-8 год, фази стаціонарного росту тривалістю 6-7 год і фази відмирання, яка починається за через 16-18 год від початку культивування [1, 5, 10-12]. Збудник $C$. perfringens типи A, B, С, Д характеризується бродильним типом метаболізму, має голофітний тип живлення та відноситься до хемотрофів за типом дихання. Ці особливості збудника нами було враховано за проведення експериментальних досліджень. У процесах дихання анаеробів приймають участь ферменти бродіння - оксиредуктази, до складу яких входять іони міді, які каталізуюють окисно-відновні реакції, та сприяють синтезу АТФ без участі кисню, розщеплюючи вуглеводи та ліпіди на прості сполуки, представляє перспективу застосування наночастинок міді для поліпшення ростових якостей живильного середовища для культивування анаеробів.

Метою роботи було визначити мінімальну концентрацію наночастинок міді (CuNP) із найвищим ефектом стимуляції метаболічних процесів у бактерій C. perfringens типи A, B, C, Д, які б забезпечували накопичення найбільших об’ємів бактеріальної маси за короткі терміни культивування.

Наукова новизна проведеної роботи представлена результатами досліджень з двох пріоритетних напрямків: вивчення характеру впливу різних концентрацій наночастинок міді на ріст і розмноження бактерій $C$. perfringens та доведення доцільності застосування стимулюючих доз наночастинок міді у біотехнології виготовлення вакцин.

Матеріали і методи досліджень. Робота виконана в лабораторії анаеробних інфекцій ім. В. Риженка IBM НААН. Наночастинки міді синтезовані в Інституті біоколоїдної хімії ім. Ф. Д. Овчаренка НАН України у вигляді колоїдного розчину з вихідною концентрацією 32,0 мг/мл за металом та розмірністю 20 нм. Нанопрепарат CuNP має паспорт безпеки 3 тестами на відсутність цитотоксичності, генотоксичності і мутагенності наночастинок міді на живі об'єкти.

Для вирощування культур анаеробів використовували традиційне рідке живильне середовище на основі бульйону Хоттінгера з вмістом амінного азоту на рівні 200,0 \pm 20,0 мг/відсотків і печінкового екстракту у співвідношенні 3 : 1. $E x$ tempore додавали стерильний $40 \%$ розчин глюкози до $10 \%$. За експериментальних досліджень до складу традиційного рідкого живильного середовища для культивування анаеробів ex tempore додавали наночастинки 
міді у вигляді колоїдного розчину із розрахунку кінцевої концентрації 0,080; 0,040 і 0,008 мг/мл за металом відповідно.

Після виготовлення рідких живильних середовищ для культивування анаеробів, традиційних та призначених для постановки експерименту, був проведений бактеріологічний контроль їхньої якості за використання тесткультури C. perfringens АТСС 13124 (одержаної із ДНКІБШМ, м. Київ) та підтверджена відповідність вимогам.

В якості об’єкту дослідження для посівів на живильне середовище iз відповідним вмістом $\mathrm{CuNP}$ використовували суспензію добових культур C. perfringens типів А, В, С, Д в об'ємі по 10,0 $\mathrm{cm}^{3}$ за концетрації 2,0×109 $\mathrm{KУO} / \mathrm{cm}^{3}$, яку визначали за допогою стандарту каламутності. Для контролю росту збудника суспензію добових культур $C$. perfringens типів $\mathrm{A}, \mathrm{B}, \mathrm{C}$, Д висівали на традиційне рідке живильне середовище без нанопрепарату. Умови pocту для C. perfringens типів А, В, С, Д, близькі до анаеробних, забезпечували шляхом нанесення на поверхню середовища 3 посівами шару стерильної вазелінової олії. Культивування культур збудника проводили в термостаті за

температури $37{ }^{0} \mathrm{C}$ упродовж 36 год. Вимірювання об’ємів бактеріальної маси C. perfringens у контрольних i дослідних живильних середовищах проводили за оптичним стандартом каламутності через 6, 12, 24 і 36 год. культивування і послідуючою інактивацією культур. Далі проводили осадження інактивованих бактеріальних клітин шляхом центрифугування при 2 тис. об./хв упродовж 20 хв. Надосадову рідину зливали, осад ресуспендували стерильним фізрозчином та порівнювали зі стандартами каламутності [13].

Статистичну обробку одержаних результатів досліджень проводили за використання програми «Excel-97» для Windows iз обчисленням середніх значень $(M)$, середньоквадратичних відхилень $(m)$ i порівняльних середніх значень із використанням параметричного $t$-критерію Стьюдента з урахуванням порогу вірогідності від $p<0,05$ до $p<0,001$ [14].

Використані методи досліджень: мікробіологічний, варіаційностатистичний.

Результати досліджень та їх обговорення. Аналіз результатів досліджень показав, що додавання наночастинок міді до складу рідкого живильного середовища для вирощування анаеробів сприяв активізації метаболічних процесів та стимулював ріст і розмноження бактеріальних клітин C. perfringens типи А, В, С, Д [15, 16]. Активізація росту збудника спостерігалася уже через 6 год, незалежно від концентрації CuNP, оскільки об’єм бактеріальної маси збільшувався вірогідно у 1,7 разів ( $>00,001)$, порівняно із показниками контролю (табл. 1).

Виражена відмінність щодо інтенсивності накопичення бактерій спостерігалася через 12 год. культивування збудника $C$. perfringens типи A, B, С, Д (рис. 1). 
Табличя 1

Особливості росту $C$. perfringens у традиційному середовищі та за додавання наночастинок міді у різних концентраціях, $M \pm m, n=5$

\begin{tabular}{|c|c|c|c|c|c|c|c|c|c|}
\hline \multirow{3}{*}{$\begin{array}{l}\text { № } \\
\text { ПI/II }\end{array}$} & \multirow{3}{*}{$\begin{array}{c}\text { Вид } \\
\text { анаеробних } \\
\text { мікроорганізмів }\end{array}$} & \multirow{3}{*}{ 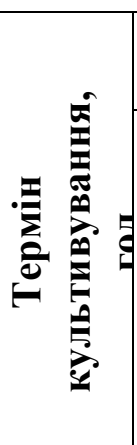 } & \multicolumn{7}{|c|}{ 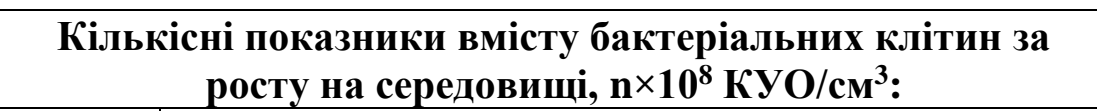 } \\
\hline & & & \multirow{2}{*}{ 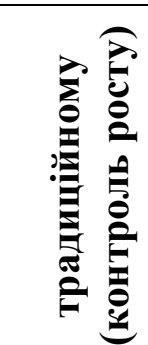 } & \multicolumn{6}{|c|}{$\begin{array}{c}\text { з додаванням наночастинок міді } \\
\text { у концентраціях, мг/мл }\end{array}$} \\
\hline & & & & $\stackrel{\infty}{\stackrel{\infty}{\circ}}$ & 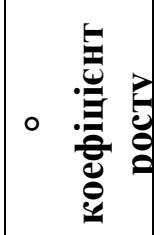 & 导 & 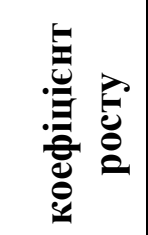 & $\stackrel{\infty}{\theta}_{\hat{\theta}}$ & 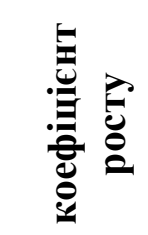 \\
\hline 1 & 2 & 3 & 4 & 5 & 6 & 7 & 8 & 9 & 10 \\
\hline \multirow[t]{6}{*}{1.} & C. perfringens тип $\mathrm{A}$ & \multirow{7}{*}{6} & 6,5 & 8,5 & 1,3 & 11,0 & 1,7 & 7,5 & 1,2 \\
\hline & - «»- тип В & & 14,0 & 23,5 & 1,7 & 22,5 & 1,6 & 28,0 & 2,0 \\
\hline & - «»- тип C & & 15,5 & 30,0 & 1,9 & 28,0 & 1,8 & 29,0 & 1,9 \\
\hline & & & \multicolumn{7}{|c|}{ (продовження табл. 1) } \\
\hline & 2 & & 4 & 5 & 6 & 7 & 8 & 9 & 10 \\
\hline & - «»- тип Д & & 7,8 & 14,0 & 1,8 & 12,0 & 1,5 & 12,0 & 1,5 \\
\hline & $(\mathrm{M} \pm \mathrm{m})$ & & $11,0 \pm 2,3$ & $19,0 \pm 3,4$ & $\begin{array}{r}1,7 \pm 0,2 \\
* * *\end{array}$ & $18,4 \pm 4,3$ & $\begin{array}{r}1,7 \pm 0,1 \\
* * *\end{array}$ & $19,1 \pm 3,4$ & $\begin{aligned} 1,7 \pm 0,2 \\
* * *\end{aligned}$ \\
\hline \multirow[t]{4}{*}{2.} & C. perfringens тип A & \multirow{5}{*}{12} & 8,0 & 13,0 & 1,6 & 13,0 & 1,6 & 11,0 & 1,4 \\
\hline & - «»- - тип В & & 16,3 & 31,0 & 1,9 & 37,0 & 2,3 & 37,0 & 2,3 \\
\hline & $-\langle\ll\rangle-$ тип C & & 23,0 & 38,0 & 1,7 & 42,0 & 1,8 & 46,0 & 2,0 \\
\hline & - «»- тип Д & & 11,9 & 16,0 & 1,3 & 18,0 & 1,5 & 22,0 & 1,9 \\
\hline & $(\mathrm{M} \pm \mathrm{m})$ & & $14,8 \pm 3,8$ & $24,5 \pm 4,3$ & $\begin{array}{r}1,6 \pm 0,2 \\
* * *\end{array}$ & $27,5 \pm 5,3$ & $\begin{array}{r}1,8 \pm 0,2 \\
* * *\end{array}$ & $29,0 \pm 6,0$ & $\begin{array}{r}1,9 \pm 0,2 \\
* * *\end{array}$ \\
\hline \multirow[t]{4}{*}{3.} & C. perfringens тип A & \multirow{5}{*}{24} & 12,0 & 14,0 & 1,2 & 27,5 & 1,8 & 29,0 & 1,9 \\
\hline & - «»- - тип В & & 23,9 & 46,0 & 1,9 & 42,0 & 1,8 & 36,0 & 1,5 \\
\hline & - «»- тип C & & 24,5 & 36,0 & 1,5 & 39,0 & 1,6 & 45,0 & 1,8 \\
\hline & - «»- тип Д & & 13,3 & 23,0 & 1,7 & 20,0 & 1,5 & 25,0 & 1,9 \\
\hline & $(\mathrm{M} \pm \mathrm{m})$ & & $18,4 \pm 3,1$ & $29,8 \pm 5,8$ & $\begin{array}{r}1,6 \pm 0,2 \\
* * *\end{array}$ & $30,3 \pm 5,5$ & $\begin{array}{r}1,7 \pm 0,1 \\
* * *\end{array}$ & $29,8 \pm 5,0$ & $\begin{array}{r}1,6 \pm 0,2 \\
* * *\end{array}$ \\
\hline \multirow[t]{4}{*}{4.} & C. perfringens тип $\mathrm{A}$ & \multirow{5}{*}{36} & 13,5 & 16,0 & 1,2 & 18,0 & 1,3 & 12,0 & 0,9 \\
\hline & — «»- тип В & & 27,9 & 46,0 & 1,6 & 40,0 & 1,4 & 34,0 & 1,2 \\
\hline & - «»- тип C & & 25,0 & 34,0 & 1,4 & 37,0 & 1,5 & 40,0 & 1,6 \\
\hline & - «»- тип Д & & 19,5 & 24,0 & 1,2 & 22,0 & 1,1 & 28,0 & 1,4 \\
\hline & $(\mathrm{M} \pm \mathrm{m})$ & & $21,5 \pm 2,1$ & $30,0 \pm 5,5$ & $\begin{array}{r}1,4 \pm 0,1 \\
* * *\end{array}$ & $29,3 \pm 4,5$ & $\begin{array}{r}1,3 \pm 0,1 \\
/ * * *\end{array}$ & $28,5 \pm 3,0$ & $\begin{array}{r}1,3 \pm 0,2 \\
* *\end{array}$ \\
\hline
\end{tabular}

Примітка: ** - p > 0,01; *** p > 0,001, порівняно із показниками контролю росту культури.

${ }^{\circ}$ коефіцієнт росту - відношення показників досліду до контрольних (Д/К). 


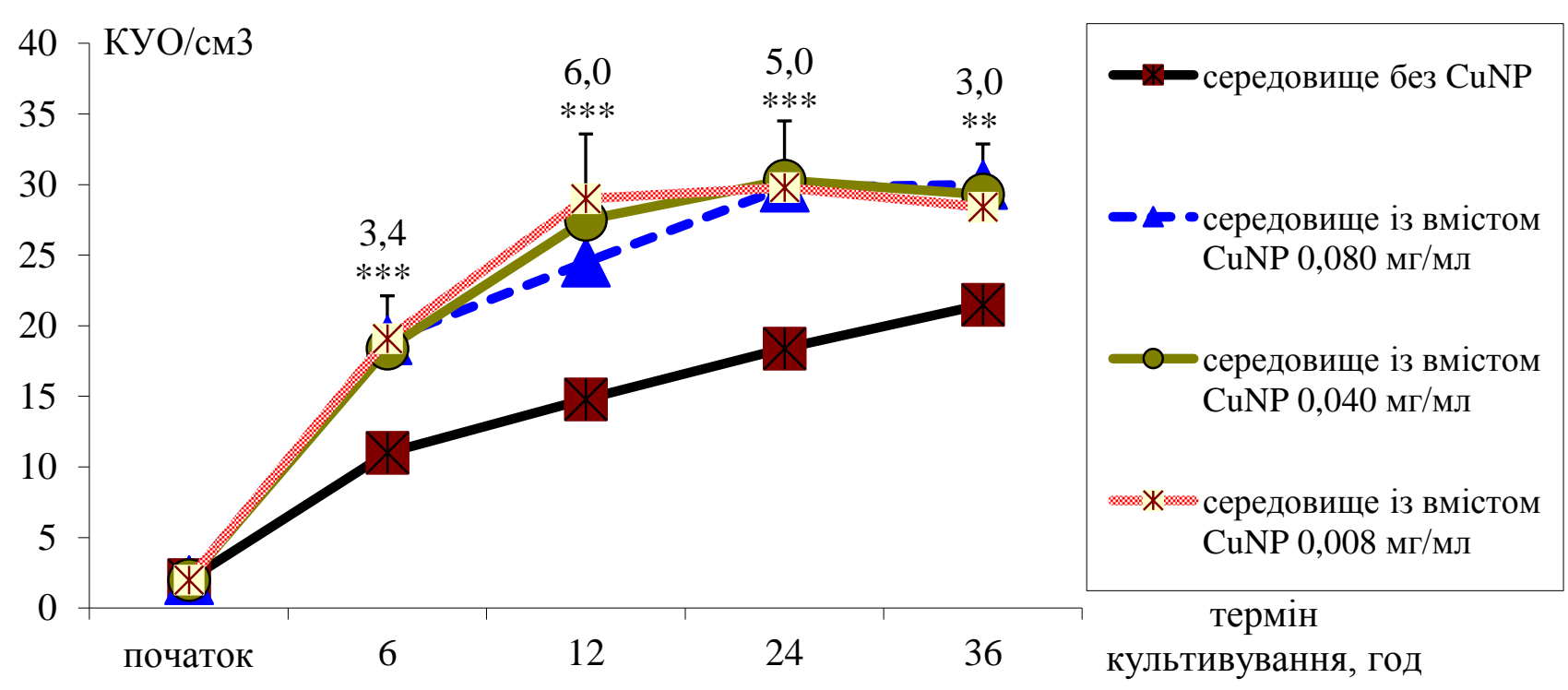

Рис. 1. Інтенсивність накопичення бактеріальних клітин $C$. perfringens y рідких живильних середовищах за різного вмісту CuNP і термінів культивування

Примітка: ** - p $>0,01 ; * * * p>0,001$, порівняно із показниками контролю росту культури.

Відмінність у активності росту залежала від концентрації нанопрепарату у живильному середовищі та у реальному часі збігалася із експоненціальною (логарифмічною) та стаціонарною фазами росту бактерій. На цей період, за культивування збудника у середовищі із вмістом у його складі CuNP на рівні 0,008 мг/мл за металом, накопичення бактеріальної маси виявилося найнижчим, оскільки ії об'єм зростав вірогідно у 1,6 разів ( $>0,01$ ), порівняно з контролем. За культивування $C$. perfringens у середовищі з концентрацією CuNP на рівні 0,040 мг/мл за металом, накопичення бактерій було вищим вірогідно у 1,8 разів $(\mathrm{p}>0,001)$, порівняно 3 контролем. Найвищий рівень стимуляції росту i розмноження бактерій $C$. perfringens типи А, В, С, Д спостерігався за додавання до складу живильного середовища наночастинок міді у розрахунку 0,008 мг/мл за металом. Встановлено, що за такої концентрації дослідного нанопрепарату одержаний об'єм бактеріальної маси культури збудника був вищим вірогідно у $1,9$ разів ( $>0,001)$, порівняно з контролем, і виявився найліпшим варіантом у виборі стимулюючих концентрацій $\mathrm{CuNP}$ для поліпшення ростових якостей живильного середовища для культивування анаеробів.

У фазу відмирання бактерій, яка починається через 16-18 год від початку інкубації бактерій і триває далі, кількісні показники накопичення клітин $C$. perfringens після 24-годинного культивування у середовищах, незалежно від концентрації у їх складі CuNP, дещо зменшувалися, порівняно 3 даними, одержаними за експоненціальної фази, проте залишалися вірогідно вищими у 1,6-1,7 разів ( $>0,001)$, порівняно 3 контролем. Через 36 год інкубації збудника C. perfringens у середовищах, незалежно від вмісту у їхньому складі CuNP, об'єми бактеріальної маси були меншими, порівняно з аналогічними за культивування упродовж 12 год, та були вищими вірогідно у 1,3-1,4 рази 
( $>0$,01), порівняно 3 контролем, що свідчило про прискорення процесів аутолізу бактеріальних клітин під дією власних ферментів.

Отже, аналіз одержаних результатів засвідчив, що поліпшення якості рідкого живильного середовища для анаеробів шляхом додавання наночастинок міді у різних концентраціях до його складу за культивування упродовж від 12 до 24 год сприяли накопиченню культури збудника C. perfringens у 1,6$1,9$ разів ( $>0,001)$, більшому вірогідно, порівняно з ростом у контролі. Найвищі ростові якості відмічені у рідкому

живильному середовищі з вмістом CuNP на рівні 0,008 мг/мл за металом.

Висновки та перспективи подальших досліджень:

1. Доведена доцільність застосування $\mathrm{CuNP}$ для поліпшення ростових якостей рідкого живильного середовища для анаеробів, оскільки наночастинки міді $\epsilon$ компонентами власних ферментів оксиредуктаз, які активізували метаболічні процеси у клітинах $C$. perfringens та стимулювали їхній ріст і розмноження.

2. Встановлено, що рідке живильне середовище для анаеробів, до складу якого вносили оптимальну стимулюючу дозу CuNP 3 розрахунку 0,008 мг/мл за металом, за культивування $C$. perfringens типи А, В, С, Д упродовж від 12 до 24 год забезпечувало накопичення найвищих об’ємів бактеріальної маси, які у 1,9 разів ( $>0,001)$ перевищували вірогідно, показники росту бактерій у контролі, що свідчить про високий рівень стимулювання обмінних процесів у клітинах збудника наночастинками міді такої концентрації.

Перспективи подальших досліджень полягають у розробці та апробації рідких i твердих живильних середовищ для вирощування анаеробних i аеробних бактерій за введення до їхнього складу композиту наночастинок міді, заліза, золота і срібла для підвищення його ростових якостей.

\section{СПИСОК ЛІТЕРАТУРИ}

1. Рєзніченко Л.С. Вплив металів-мікроелементів на функціональний стан бактерійпробіонтів / Л.С. Рєзніченко, Т.Г. Грузіна, В.В. Вембер та ін. // Укр. біохім. журн. - 2008. T. 80., № 1. - C. 96-101.

2. Chen Z. Acute toxicological effects copper Nanoparticles in vivo / Z. Chen, H. Meng, G. Xing et al. // Toxicology Letters. - 2006. - Vol. 163, N 2. - P. 109-120.

3. Чекман I.C. Нанофармакологія: стан та перспективи наукових досліджень / I.C. Чекман, О.В. Ніцак // Вісн. фармакол. та фармації. - 2007. - № 11. - С. 7-10.

4. Москаленко В.Ф. Нанонаука, нанобіотехнології, наномедицина, нанофармакологія / В.Ф. Москаленко, І.С. Чекман, Н.О. Горчакова та ін. // Укр. наук.-метод. молодіжний журн. «YouthNanoBioTest». - 2010. - «Молодіжний форум з нанобіотехнологій»: матеріали конф. (19 травня 2010 р., Київ). - № 3. - С. 9-16.

5. Gant V.A. Three novel highly charged copper-based biocides: safety and efficacy against healthcare - associated organisms / V.A. Gant, M.W. Wren, M.S. Rollins et al. // J. Antimicrob. Chemother. - 2007. - Vol. 60, N 2. - P. 294-299.

6. Картель М.Т. Концепція методології ідентифікації та токсикологічних досліджень наноматеріалів і оцінки ризику для людського організму та довкілля при їх виробництві i застосуванні / М.Т. Картель, В.П. Терещенко // Химия, физика и технологии поверхности: межвед. Сб. науч. Тр. - К.: Наукова думка, 2008. - Вып. 14. - С. 565-583. 
7. Hernandez-Sierra J.F. The antimicrobial sensitivity of Streptococcus mutants to nanoparticles of silver, zinc oxide, and gold / J.F. Hernandez-Sierra, F. Ruiz, D.C. Cruz Pena, F. Martinez-Gutierrez // Nanomedicine. - 2008. - N 17. - P. 19.

8. Бабушкина И.В. Изучение антибактериального действия наночастиц меди и железа на клинические штаммы Staphylococcus aureus / И.В. Бабушкина, В.Б. Бородулин, Г.В. Коршунов и др. // Саратов. науч.-мед. журн. - 2010. - Т. 6, № 1. - С. 11-14.

9. Богословская О.А. Изучение безопасности введения наночастиц меди с различными физико-химическими характеристиками в организм животных / О.А. Богословская, Е.А. Сизова, В.С. Полякова и др. // Вести Оренбург. гос. ун-та. - 2009. - № 2. - С. 124-127.

10. Мартынова С. Н. Метаболические эффекты меди и кобальта / С. Н. Мартынова, В.Н. Зовский // Експериментальна і клінічна медицина. - 2010. - № 2. - С. 42-49.

11. ISO/TS 11133-2:2003 Мікробіологія харчових продуктів та кормів для тварин. Настанови щодо готування та виробництва поживних середовищ. Частина 2. Практичні настанови щодо випробування культуральних середовищ.

12. Методические рекомендации к контролю питательных сред по биологическим показателям. - М., 1980. - 187 с. - Библиограф.: С. 142-147.

13. Імунологічні методи досліджень у лабораторіях ветеринарної медицини: Методичні рекомендації / В.М. Івченко, П.І. Сидорчук, М.С. Павленко та ін. - Біла Церква, 1997.- C. 19-20.

14. Ойвин И.А. Статистическая обработка результатов экспериментальных исследований / И.А. Ойвин // Патологическая физиология и экспериментальная терапия.1960.- № 4.- С. 396-401.

15. Поздеев О К. Медицинская микробиология: учебное пособие / Под ред. И.В. Покровского. - М.: ГЭОТАР-Медиа, 2008. - 765 с.

16. Спеціальна, клінічна і екологічна мікробіологія: методичні вказівки для студентів медичного ф-ту / Упор.: А.Я. Циганенко, В.В. Мінухін, Н.В. Павленко та ін. - Харків: ХНМУ, 2009. - 124 с. - Бібліограф.: С. 45-54.

СПОСОБ УЛУЧШЕНИЯ РОСТОВЫХ КАЧЕСТВ ПИТАТЕЛЬНЫХ СРЕД ДЛЯ АНАЕРОБОВ ПРИ ИСПОЛЬЗОВАНИИ НАНОЧАСТИЦ МЕДИ / МИНџЮК Е.П., Нычик С.А., Горбатюк О.И., Рыженко Г.Ф., Андриящук В.А., Жовнир А.Н., Уховская Т.Н., Тютюн С.Н., Резниченко Л.С., Дыбкова С.Н.

В статье представлен анализ результатов экспериментальных исследований, которые были связаны с улучшением ростовых качеств жидкой питательной среды для анаэробных бактерий $C$. perfringens muпы $A, B, C$, Д после введения в их состав наночастиц меди (СuNP) в концентрациях 0,080; 0,040 и 0,008 мг/мл с иелью накопления больших объемов бактериальной массы возбудителя за краткие строки культивирования. Статья содержит результаты исследований, которые подтверждают иелесообразность использования наночастии меди для улучшения качества жидкой питательной среды $и$ активизации роста C. perfringens типь $A, B$, С, Д в конщентращии 0,008 мг/мл за металлом, что обеспечивало повышение объема бактериальной массы возбудителя достоверно в 1,9 раза (р>0,001), сравнительно из аналогичными показателями при ее росте в жидкой питательной среде без содержания CuNP, в течении 12 час культивирования в термостате при $37^{\circ}$ C, что имеет важное значение в биотехнологии изготовления вакиин.

Ключевые слова: жидкая питательная середа для анаэробов, наночастищь меди, CuNP, концентрация нанопрепарата, C. perfringens, интенсивность роста, бактериальная мacca. 


\section{METHOD OF IMPROVING GROWTH QUALITIES OF THE ANAEROBIC NUTRIENT MEDIUM WITH COPPER NANOPARTICLES / Mintsyuk E., Nychyk S., Gorbatyuk O., Ryzhenko G., Andriyaschuk V., Zhovnir A., Ukhovska T., Tyutyun S., Reznichenko L., Dibkova S.}

Introduction. Studying the features of metal nanoparticles influence on metabolic processes of bacterial cells are now an urgent task of medicine, biology and biotechnology since there is little scientific information on the use of metal nanoparticles as stimulators of growth and reproduction of bacterial pathogens.

The goal of the work. Determination of the minimum concentration of copper nanoparticles $(\mathrm{CuNP})$ with the highest effect on stimulation of metabolic processes in bacteria $C$. perfringens (types $A, B, C, D$ ), which would ensure the accumulation of the largest volumes of bacterial mass for short cultivation time.

Materials and methods. The work was done in the laboratory of anaerobic infections nd. a. V. Ryzhenka IVM NAAN. Copper nanoparticles synthesized at the F. D. Ovcharenko Institute of Biocolloidal Chemistry of the National Academy of Sciences of Ukraine in the form of a colloidal solution with an initial metal concentration of 32,0 $\mathrm{mg} / \mathrm{ml}$ and a dimension of $20 \mathrm{~nm}$. The CuNP has a safety passport with tests for the absence of cytotoxicity, genotoxicity and mutagenicity of copper nanoparticles on living objects.

The object of the study was suspension of $C$. perfringens daily cultures (types $A, B, C, D$ ) in concentration 2,0 × $109 \mathrm{CFU} / \mathrm{cm}^{3}$.

Measurement of the $C$. perfringens bacterial mass volume was carried out according to the optical standard of turbidity after 6, 12, 24 and 36 hours of cultivation.

Used research methods: microbiological, variational-statistical.

Results of research and discussion. According to the results of the research, it has been established that activation of the $C$. perfringens ( $A, B, C, D$ types) growth was observed after 6 hours of cultivation in nutrient media regardless of the concentration of CuNP in it. The volume of bacterial mass increased in the 1,7 times ( $p>0,001)$, compared with control indicators.

The highest level of growth stimulation and reproduction of $C$. perfringens bacteria was observed with adding copper nanoparticles to a nutrient medium in concentration $0,008 \mathrm{mg} / \mathrm{ml}$. At such concentration of experimental nanoparticle, the amount of obtained bacterial mass of the pathogen was higher, probably more than 1,9 times ( $p>0.001$ ), as compared with control, and was optimal for improvement the growth qualities of the anaerobic nutrient medium.

The accumulation of $C$. perfringens cells after 24 hours of cultivation in the nutrient medium, regardless of concentration CuNP in it, decreased, compared with data obtained after 12 hours of growth, but remained significantly higher at 1,6-1,7 times ( $p>0.001)$ compared with control. After 36 hours of incubation of $C$. perfringens in nutrient medium, regardless of concentration CuNP in it, the bacterial mass volumes were smaller compared to similar cultivations for 12 hours and were higher in the range of 1,3-1,4 times ( $p>0,01)$, compared to control, this indicates acceleration of autolysis of bacterial cells under the influence of their own enzymes.

Conclusions and prospects for further researches.

1. The feasibility of using CuNP to improve the growth qualities of the liquid nutrient medium for anaerobes is proved, because copper nanoparticles are components of the oxyreductase enzymes in $C$. perfringen cells that activate metabolic processes and stimulate their growth and reproduction.

2. The liquid nutrient medium for anaerobes, which included the optimum stimulating dose of CuNP in concentration $0,008 \mathrm{mg} / \mathrm{ml}$, used for cultivation of $C$. perfringens types $A, B, C, D$ for the period from 12 to 24 hours provided the accumulation of the highest volumes of bacterial mass, which was 1,9 times higher ( $p>0,001)$ than the bacterial growth rates in the control. It indicates a high level of metabolic processes stimulation in the cells of the pathogen by copper nanoparticles of this concentration. 
Further studies are in development and testing of liquid and solid nutrient medium with adding to it a composite of copper, iron, gold and silver nanoparticles to enhance its growth qualities for the cultivation of anaerobic and aerobic bacteria.

Keywords: liquid nutrient medium for anaerobes, copper nanoparticles, CuNP, C. perfringens, growth rate, bacterial mas.

\section{REFERENCES}

1. Rjeznichenko, L. S., Gruzina, T. G., Vember, V. V. et al. (2008). Vplyv metalivmikroelementiv na funkcional'nyj stan bakterij-probiontiv [Influence of microelement metals on the functional state of bacteria probionts]. Ukr. biohim. Zhurnal - The Ukrainian Biochemical Journal, Is. 80, 1, 96-101 [in Ukrainian].

2. Chen, Z., Meng, H., Xing, G. et al. (2006). Acute toxicological effects copper Nanoparticles in vivo. Toxicology Letters, 163, No. 2, 109-120.

3. Chekman, I.S. \& Nicak, O.V. (2007). Nanofarmakologija: stan ta perspektyvy naukovyh doslidzhen' [Nano Pharmacology: the state and prospects of scientific research]. Visn. farmakol. ta farmacii' - Bulletin pharmacologist and pharmacy, 11, 7-10 [in Ukrainian].

4. Moskalenko, V.F., Chekman, I.S., Gorchakova, N.O. et al. (2010). Nanonauka, nanobiotehnologii', nanomedycyna, nanofarmakologija [Nanoscience, Nanobiotechnology, Nanomedicine, Nanopharmacology]. Ukr. nauk.-metod. molodizhnyj zhurn. "YouthNanoBioTest»Ukr sci. method. youth journal «YouthNanoBioTest», 3, 9-16 [in Ukrainian].

5. Gant, V.A., Wren, M.W., Rollins, M.S., et al. (2007). Three novel highly charged copperbased biocides: safety and efficacy against healthcare - associated organisms. J. Antimicrob. Chemother., Vol. 60, No. 2, 294-299.

6. Kartel, M.T. \& Tereshhenko, V.P. (2008). Koncepcija metodologii' identyfikacii' ta toksykologichnyh doslidzhen' nanomaterialiv i ocinky ryzyku dlja ljuds'kogo organizmu ta dovkillja pry i'h vyrobnyctvi i zastosuvanni [Concept of the methodology of identification and toxicological studies of nanomaterials and risk assessment for the human organism and the environment during their production and application]. Himija, fizika i tehnologii poverhnosti-Chemistry, physics and surface technology, 14, 565-583 [in Russian].

7. Hernandez-Sierra, J.F., Ruiz, F., Cruz Pena, D.C., \& Martinez-Gutierrez, F. (2008). The antimicrobial sensitivity of Streptococcus mutants to nanoparticles of silver, zinc oxide, and gold. Nanomedicine, 17, 19.

8. Babushkina, I.V., Borodulin, V.B. \& Korshunov, G.V. (2010). Izuchenie antibakterial'nogo dejstvija nanochastic medi i zheleza na klinicheskie shtammy Staphylococcus aureus [Study of antibacterial action of copper and iron nanoparticles on clinical strains of Staphylococcus aureus]. Saratov. nauch.-med. zhurn. - Saratov scientific-medical journal, 6, No. 1, 11-14 [in Russian].

9. Bogoslovskaja, O.A., Sizova, E.A., Poljakova, V.S. et al. (2009). Izuchenie bezopasnosti vvedenija nanochastic medi $\mathrm{s}$ razlichnymi fiziko-himicheskimi harakteristikami $\mathrm{v}$ organizm zhivotnyh [A study of the safety of the introduction of copper nanoparticles with various physicochemical characteristics in the animal's organism]. Vesti Orenburg. gos. un-ta-News of the Orenburg. state university, 2, 124-127 [in Russian].

10. Martynova, S.N., \& Zovskij, V.N. (2010). Metabolicheskie jeffekty medi i kobal'ta [Metabolic effects of copper and cobalt]. Eksperymental'na i klinichna medycyna - Experimental and Clinical Medicine, 2, 42-49 [in Russian].

11. Mikrobiologija harchovyh produktiv ta kormiv dlja tvaryn. Nastanovy shhodo gotuvannja ta vyrobnyctva pozhyvnyh seredovyshh. Chastyna 2. Praktychni nastanovy shhodo vyprobuvannja kul'tural'nyh seredovyshh [Microbiology of food and animal feed. Guidelines for the preparation and production of nutrient media. Part 2. Practical guidelines for testing culture media]. (2008). ISO/TS 11133-2:2003 from 2008. Kyi'v: Derzhspozhyvstandart Ukrai'ny [in Ukrainian].

12. Metodicheskie rekomendacii $\mathrm{k}$ kontrolju pitatel'nyh sred po biologicheskim pokazateljam [The control of nutrient media by biological indicators]. (2008). Guidelines. Moscow [in Russian]. 
13. Ivchenko, V.M., Sydorchuk, P.I., \& Pavlenko, M.S. Imunologichni metody doslidzhen' u laboratorijah veterynarnoi' medycyny [Immunological methods of research in laboratories of veterinary medicine]. (1997). Guidelines. Bila Cerkva [in Ukrainian].

14. Ojvin, I.A. (1960). Statisticheskaja obrabotka rezul'tatov jeksperimental'nyh issledovanij [Statistical processing of the results of experimental studies]. Patologicheskaia fiziologiia $i$ eksperimentalnaia terapiia - Pathological physiology and experimental therapy, 4, 396-401 [in Russian].

15. Pozdeev, O.K. (2008). Meditcinskaia mikrobiologiia: uchebnoe posobie [Medical microbiology: manual]. I.V. Pokrovskii (Ed.). M.: GEOTAR-Media [in Russian].

16. Cyganenko, A.Ja., Minuhin, V.V., \& Pavlenko, N.V. (2009). Special'na, klinichna i ekologichna mikrobiologija [Special, clinical and environmental microbiology]. Guidelines. Harkiv: HNMU [in Ukrainian].

\section{УДК 636.5:619:616.9:619:616.981.459:619:616.995.132(477)}

ПЛИС В.М., канд. вет. наук, ст. наук. сп., e-mail: inst_zerna@mail.ru Державна установа Інститут зернових культур Національної академії аграрних наук України

\section{ЕПІЗООТОЛОГІЧНИЙ МОНІТОРИНГ ПАСТЕРЕЛЬОЗНО- АСКАРИДІОЗНОГО МІКСТ ЗАХВОРЮВАННЯ ПТИЦІ НА ТЕРИТОРІЇ УКРАЇНИ (2012-2016 РР.)}

Встановлено динаміку зростання кількості спалахів захворювання у птиці упродовж останніх п'яти років. Особливо цей показник різко зріс у птахомолодняку в період 2016 року в середньому у курчат 8-120-денного віку - на 8\%, курчат 5-6-місячного віку - на 7\%, каченят 40-45-денного віку - на 7\%, в період 2015 року у гусенят 50-60-денного віку - на $8 \%$ порівняно з 2012 роком. У більшості випадків захворювання зустрічається в приватному секторі серед курей та водоплавної птиці, при иььому має місце пастерелоаскаридіоносійство.

При цьому високу інфікованість птиці пастерельозно-аскаридіозним мікст захворюванням без прояву клінічних ознак - вільні від пастерел і аскаридій - 15\%, пастерелоаскаридіоносійство сягає 60\%, захворюваність птиці на пастерельозно-аскаридіозне мікст захворювання з клінічним проявом складає - $20 \%$, летальність сягає до $5 \%$.

Ключові слова: епізоотологічний моніторинг, птиця, бактерії, гельмінти

Вступ. Однією з найпотужніших галузей в тваринництві є птахівництво. Значно збільшити виробництво м'яса і яйця птиці за короткий термін можливо за рахунок вирощування найбільш скоростиглих кросів та порід птиці $[4,6]$.

Переведення птахівництва на промислову основу і висока концентрація птиці на обмеженій території вимагають жорсткого дотримання протиепізоотичних заходів, спрямованих на охорону птахогосподарства від заносу інфекції із-зовні [5].

Зосередження птиці на обмеженій території закономірно призвела до виникнення нових взаємин між мікро- і макроорганізмом. У результаті цього виникли змішані захворювання птиці, за яких різко змінилися патогенез, клінічні ознаки, патолого-анатомічні і пато-гістологічні зміни, що утруднило 